\title{
Probability of Mergers and Acquisitions Deal Failure
}

\author{
Sailesh Tanna, Ibrahim Yousef, Matthias Nnadi \\ Sailesh Tanna (Centre of Financial and Corporate Integrity and School of Economics Finance and Accounting, Coventry \\ University, Coventry, UK) \\ Ibrahim Yousef (Department of Banking and Finance, University of Petra, Amman, Jordan) \\ Matthias Nnadi (Department of Finance and Accounting, Cranfield University, Bedford, UK)
}

\begin{abstract}
This study investigates whether the likelihood of deal success/failure in merger transactions is influenced by the underlying characteristics which tend to affect acquirers' shareholder returns. These characteristics include the method of payment (cash versus stock), target status (listed versus non-listed targets), diversification (domestic versus cross-border and industry-wide deals), and acquirers' prior bidding experience. We also investigate whether announced deals reflect an expectation about the likelihood of deal completion. The findings from event study confirm that market reaction is indifferent to whether the announced deals are likely to be successfully completed or not, consistent with the efficient markets hypothesis. However, the results from probit regressions confirm that the aforementioned deal characteristics, as well as certain firm and country level factors, influence the likelihood of whether previously announced deals are subsequently completed or cancelled.
\end{abstract}

\section{JEL Classification: G34, G14}

Keywords: Mergers and Acquisitions; Event Study, Abnormal Returns, Probit regressions 


\section{Introduction}

Mergers and acquisitions (hereafter M\&As) involve complex deals and their precise impact on shareholder wealth is an area that has been debated from various perspectives in the mainstream literature. One line of research focusses on whether M\&As tend to improve or destroy shareholder wealth, and many studies have examined market reactions to announcements of M\&As using event study methodology. The picture provided by the existing literature regarding the overall effects of M\&As on shareholder wealth, however, is far from clear. While there is a general trend indicating that target companies tend to earn positive announcement period returns, evidence on acquiring company (or bidder ${ }^{1}$ ) returns has been quite mixed. Most notably, the literature has related shareholder returns to (i) the method of payment used to finance the deal, distinguishing between cash or stock payment (or a combination of both), (ii) the role and nature of information asymmetry surrounding the status of target firms (whether publicly-listed or private), (iii) industry or cross-border diversification, and (iv) acquirer characteristics such as size and experience. Investigation of such relationships is typically determined by combining event study with regression methods (see e.g. Mulherin and Boone 2000, Kohers and Kohers 2000, Andrade et al. 2001, Beitel et al. 2004, Choi and Russell 2004, Mai et al. 2009, Martynova and Renneboog 2011, Jaffe et al. 2015).

Another dimension of M\&A research relates to the pre-merger characteristics of targets and acquirers that affect their likelihood of being involved in M\&As. The literature in this regard offers evidence relating to both financial and non-financial firms, focussing on specific regions, such as the USA, Europe, and Asian countries (e.g. Powell 1997, Gonzalez et al. 1997, AliYrkko et al. 2005, Wheelock and Wilson 2004, Rossi and Volpin 2004, Focarelli and Pozollo 2001, Buch and DeLong 2004, Hannan and Pilloff 2009, Pasiouras et al. 2011). Studies in this area have largely employed Logit or Probit regressions using samples of involved firms in M\&A transactions (i.e. targets/acquirers) combined with non-involved peers. Owing to the nature of the investigation, most of the studies in this area have used data on completed M\&A transactions only, thereby ignoring deals that ultimately failed.

An interesting extension to this area of research, not explored in previous studies, is to examine whether specific characteristics influencing shareholder wealth upon merger announcements will also affect the likelihood that such M\&As will eventually succeed or (otherwise) fail. As noted above, prior empirical studies on shareholder wealth effects of M\&As have largely used

\footnotetext{
1 The terms 'acquirers' and 'bidders' are used interchangeably as is conventional in the literature.
} 
completed deals - thus ignoring unsuccessful deals (Mangold and Lippok 2008, Officer et al, 2009, Rani et al. 2014, Jaffe et al. 2015). ${ }^{2}$ Among other aspects of research on M\&As, Hensher and Jones (2007) suggest an approach for selecting a suitable predictable model for estimating distress firms, while Peat (2007) highlights the importance of developing a hazard-type model in the validation of bankruptcy and takeovers. While there is abundance of research on the impact of M\&As (Baskerville and Hay, 2006), research on predicting the success/failure of such merger deals is relatively scarce. This study aims to examine the factors affecting the likelihood of M\&A deal failures once announced.

In the literature there are some related studies which have focussed on analysing successful or failed takeover deals from various perspectives. Tang (2015), for example, examine acquirers' termination returns in failed deals and find that acquirer gains vary significantly depending on target type. Becher et al. (2015) analyse the impact of analyst recommendations on the probability of deal success and find that it increases (decreases) along with the favourability of acquirer (target) recommendations. Malmendier et al. (2016) analyse unsuccessful takeover bids and find that the targets of cash offers are revalued, on average, by $+15 \%$ after deal failure, whereas stock-funded targets returned to their pre-announcement levels. Caiazza and Pozzolo (2016) investigate the relevance of several characteristics in explaining failed announced deals from the banking industry, including diversification (domestic versus cross-border deals), the hostility of the bidder and the presence of multiple potential acquirers. More recently, Alhenawi and Stilwell (2017) identify several reasons consistent with relevant theories in explaining value creation from $M \& A s$ and the successful completion of such deals, attributing to factors such as the acquirer's historical performance and target's pre-merger value. We built upon this stand of the literature to analyse the impact of several deal-specific attributes on the probability of M\&A deal failure. In a sense, this strand of research is still in its infancy, and our study adds to a limited number of recent studies by providing robust evidence based on a worldwide sample of M\&A deals.

With this aim in mind, it seems natural to ask whether the market reaction at the time of deal announcement reflects an expectation regarding subsequent deal completion, which may be influenced by specific deal characteristics associated with bidder shareholder returns or premerger risk (Tanna and Yousef, 2019). According to the informational efficiency of markets, the market reaction at the time of deal announcement should reflect all (publicly) available

\footnotetext{
2 Moeller, Schlingemann, and Stulz (2004: 205) indicated that "to estimate the shareholder gains from acquisitions, we consider successful and unsuccessful acquisition announcements to investigate whether this focus introduces a bias in our analysis and find that it does not".
} 
information regarding the deal, including both deal and firm-level characteristics. Conversely, if the market reflects any uncertainty about deal completion at the time of announcement, this would be inconsistent with the efficient market hypothesis. The implicit assumption underlying this reasoning is that the market reaction from deal announcement would be indifferent to the likelihood of the deal being successfully completed or not. Addressing this kind of enquiry requires using relevant data for a sample combining both successful (i.e. completed) and unsuccessful (i.e. cancelled) deals to avoid any sample selection bias, and analysing announcement period abnormal returns using event study methodology supplemented by Probit regressions. We undertake a unique study of this kind, using an extensive, global sample of 46,758 M\&A deals from 180 countries and 80 industries, which took place between the years 1977 and 2012. ${ }^{3}$

Our results indicate that there are no significant differences in announcement returns between successful and unsuccessful deals. This indicates that market reaction to deal announcement does not reflect an expectation of whether deal completion is likely or not, a finding which is consistent with the efficient market hypothesis - since abnormal returns are not impacted by uncertainty about deal completion or failure. With regard to specific deal factors, we find that domestic and focussed deals are negatively associated with the likelihood of deal failure, while the effect of diversified deals is positive. This suggests that domestic and focussed deals are more likely to be successfully completed than cross-border or cross-industry deals, an outcome which appropriately reflects the higher degree of information asymmetry associated with more diversified deals. Our results also reveal that cash payment deals increase the likelihood of deal completion, while stock payment deals support the opposite result. This finding may also be associated with information asymmetry surrounding bidder/target valuation, as cash deals tend to be more favourable from the point of view of target companies as a way of distinguishing high-value bidders from low-value bidders. We also find that deals involving public targets increase the probability of deal failure, relative to deals involving private targets. Finally, we find that acquirer prior experience is positively associated with the likelihood of deal failure.

\footnotetext{
${ }^{3}$ Prior studies in the literature have used much smaller samples, typically less than 1000 deals. To give some examples, Raj and Uddin (2013) used a sample of 340 deals in the UK, Rani et al. (2014) used 268 deals, Bhabra and Huang (2013) used 136 completed domestic and cross-border deals. Studies involving relatively larger samples include Ahern (2007), who used a sample of 12,942 deals, and Moeller, et al. (2005), whose sample included 12,023 acquisitions. At the middle of the spectrum, Andrade, et al. (2001) and Martynova and Renneboog (2011) looked at 3,688 and 2,149 acquisitions, respectively. Fuller, et al. (2002) used 3,135. Faccio, et al. (2006) looked at 4,429, and the sample of Jaffe, et al. (2015) contained 835 acquisitions of subsidiaries and 2,571 acquisitions of public targets. Our sample, by contrast, is much larger and includes all M\&A deals, both completed and cancelled, obtained from Thomson One Banker SDC M\&A Database.
} 
The remainder of this paper is organised as follows: Section 2 provides a discussion of the sampling procedure used for data collection. Section 3 presents the relevant hypotheses and outlines the methodological approach. Section 4 discusses the empirical results, which include univariate tests based on event study results and multivariate analysis summarising the results of Probit regressions. Section 5 concludes.

\section{Sampling and Data Collection}

The worldwide sample of deals used in this study, along with associated share price information for acquirers, covers 180 countries and 88 sub-industries, which have been chosen on the basis of data availability. The information is sourced primarily from two databases, SDC M\&A Database and Datastream. The M\&A data include, as far as possible, all initial bids announced between 1970 and 2012. The criteria for inclusion in the sample are:

1. The acquirer is a public firm.

2. The target is a public, private, or subsidiary firm.

3. The acquirer's market share prices and local index prices are available in DataStream.

4. The type of transaction is coded either ' 1 ' or ' 2 ', where $1=$ Disclosed Value (indicates all deals that have a disclosed dollar value, and the acquirer is acquiring an interest of $50 \%$ or more in a target, raising its interest from below $50 \%$ to above $50 \%$, or acquiring the remaining interest it does not already own), and $2=$ Undisclosed Value (indicates all deals that do not have a disclosed dollar value, and the acquirer is acquiring an interest of $50 \%$ or more in a target, raising its interest from below $50 \%$ to above $50 \%$, or acquiring the remaining interest it does not already own).

5. Status of Transaction: $\mathrm{C}, \mathrm{W}$, where $\mathrm{C}=$ Completed (the transaction has closed), and $\mathrm{W}=$ Withdrawn (the target or acquirer in the transaction has terminated its agreement, letter of intent, or plans for the acquisition or merger).

6. Value of Transaction: $\$ 1$ million or more, i.e. the total value of consideration paid by the acquirer, excluding fees and expenses.

7. Percentage of Shares Owned After Transaction: From below 50\% up to $100 \%$. This represents the number of common shares acquired in the transaction plus any shares previously owned by the acquirer divided by the total number of shares outstanding.

Based on the above criteria, the total sample includes 46,758 initial bids, of which 36,489 deals were successfully completed while 10,269 deals were cancelled. Appendix 1-5 lists the relevant details including target and acquirer countries, industries and number of deals per year. 


\section{Empirical Strategy}

\subsection{Hypotheses}

According to the efficient market hypothesis (EMH), any market reaction to deal announcement should reflect all available information including relevant deal, firm, or countrylevel characteristics. That said, there is always future uncertainty about whether a deal will eventually be completed or fail once announced. Therefore, it is important to investigate whether the market reaction around deal announcement reflects an expectation regarding deal failure, an assumption that is inconsistent with the EMH. Thus our main hypothesis is whether market reaction is indifferent to whether announced deals are likely to be successfully completed or not.

H1: There are no significant differences in announcement period abnormal returns between deals that are eventually successful (completed) or unsuccessful (cancelled).

Testing this hypothesis involves an examination of announcement period return differentials from event study before and after deal announcement, as well as including a factor that reflects an expectation of deal completion in Probit regressions. Since our sample includes both successful and unsuccessful deals, it seems appropriate to consider whether specific deal, firm, and country-level characteristics influence the probability of deal success/failure once announced. Hence, it seems sensible to investigate whether the likelihood of deal failure, once a merger deal has been agreed and announced, is affected by the relevant deal characteristics that distinguish between (i) cash or stock payment offered for the deals, (ii) deals involving public and non-public targets, (iii) deals that are focussed versus diversified, and (iv) deals distinguished according to acquirers' previous experience of acquisitions (serial acquirers). As such, the analysis aims to investigate the following additional null hypotheses:

$\mathrm{H} 2$ : There are no significant differences in the probability of deal failure between cash and stock payment deals.

H3: There are no significant differences in the probability of deal failure between focussed and diversified deals.

H4: Target status (where public on non-public) has no impact on the probability of deal failure.

H5: Acquirers' prior acquisition experience has no impact on the probability of deal failure. 
All the above hypotheses are investigated using both univariate analysis, which summarise event study results, and multivariate analysis using Probit estimation to test the influence of relevant conditioning variables on the probability of deal failure. 


\subsection{Event Study}

We follow Brown and Warner's (1985) and Fuller et al.'s (2002) event study methodology to calculate acquirers' abnormal returns for a up to 10 days before and after the announcement date. Abnormal returns are calculated by subtracting the actual returns during the event window from expected returns (MacKinlay, 1997). Specifically, for acquirer $i$ in period $t$, the abnormal return is calculated as follows:

$A R_{i, t}=r_{i, t}-E\left(r_{i, t}\right)$

where $A R_{i, t}$ is the abnormal return for stock $i$ at time $t ; r_{i, t}$ the actual return on stock $i$ at time $t$; and $E\left(r_{i, t}\right)$ the expected return on stock $i$ at time $t$

The expected returns are derived using the market model, which expresses the relation between expected and market returns as follows:

$E\left(r_{i, t}\right)=\alpha+\beta r_{m, t}+\varepsilon_{i, t}(t=-110, \ldots,-11)$

where $r_{m, t}$ is the market return (determined using a benchmark local market index) at time $t$; and $\varepsilon_{\mathrm{i}, \mathrm{t}}$ is the random error term.

The parameters of equation (2) are estimated using acquirers' daily stock price data (converted into returns using log differences) over the period from 110 days to 11 days prior to deal announcement date. The average abnormal returns (AARs) and cumulative abnormal returns (CARs) are then calculated according to the formula:

$$
\begin{aligned}
& A A R s=\frac{1}{N} \sum_{i=1}^{N} \widehat{A R}_{i, t} \\
& \operatorname{CARs}\left(T_{1}, T_{2}\right)=\sum_{t=T_{1}}^{T_{2}} \widehat{A R}_{i, t}
\end{aligned}
$$

where $\widehat{A R}_{i, t}$ is the calculated abnormal return for each stock $i$ at time $t ; N$ constitutes the number of deals, and $T_{1}$ and $T_{2}$ reflect the start and end dates of the event window around the announcement date. (Can you check if Equation 4 is correct??)

\subsection{Probit Regression}


The base category for the dependent variable in the probit model, specified below, is that the deal is successful after it has been announced. Thus, the dependent variable is binary: equal to ' 1 ' if the deal is cancelled and ' 0 ' if the deal is completed:

$Z_{i}=\left\{\begin{array}{l}1 \text { for cancelled deal } \\ 0 \text { for completed deal }\end{array}\right.$

The specification of the probit model takes the form:

$\operatorname{Pr}(\mathrm{Z}=1 \mid \mathrm{x})=\alpha+\beta_{d}$ Deal $_{i}+\beta_{f}$ Firm $_{i}+\beta_{c}$ Country $_{i}+\varepsilon_{i}$

where $\alpha$ is the intercept term; and $\beta_{\mathrm{d}}, \beta_{\mathrm{f}}$, and $\beta_{\mathrm{d}}$ are the coefficients associated with the corresponding set of explanatory variables representing deal, firm, and country level characteristics.

In the empirical analysis, consistent with hypotheses $\mathrm{H} 2-\mathrm{H} 5$ above, we include four sets of deal characteristics, representing the method of payment, target status, diversification, and acquirer prior bidding experience, along with a host of firm level and country level control variables. More precisely, in relation to the method of payment, we distinguish between cash $(\mathrm{CSH})$ and stock (STC) payment deals. On target status, we distinguish between public $(P u b)$, private (Priv) and subsidiary (Subs) targets. In testing the impact of diversification, we distinguish between domestic and focussed $(D A F)$, domestic and cross-industry $(D C I)$, cross-border and focussed $(C B F)$, and cross-border and cross-industry $(C B C I)$ deals. As for acquirer prior experience (Exp), this is represented by the cumulative number of previous takeovers by the same acquirer in previous three years.

Taking these factors into account, a detailed empirical specification of the probit model, including all the control variables, is as follows:

$\operatorname{Pr}(\mathrm{y}=1 \mid \mathrm{x})=\alpha+B_{1} D A F_{i}+B_{2} D C I_{i}+B_{3} C B F_{i}+B_{4} C B C I_{i}+B_{5} C S H_{i}+B_{6} S C_{i}+B_{7} P u b_{i}+$ $B_{8}$ Priv $_{i}+B_{9}$ Subs $_{i}+B_{10}$ Exp $_{i}+B_{11} V T_{i}+B_{12} G D P_{j}+B_{13} \frac{M}{B_{i}}+B_{14} A S_{i}+B_{15} L I Q_{J}+B_{16} I P_{j}+$ $B_{17} C_{C A R_{j}}+B_{18}$ Pre_Beta $+\varepsilon_{i}$

The control variables included in the above model allow for both firm-level and countryspecific heterogeneity. These are: $V T_{i}$ which denotes the value of transaction, representing target size; $G D P_{j}$ represents GDP per capita of country $j$ where the target is located; $A S_{i}$ represents acquirer's size; $L I Q_{j}$ is the legal institutional quality indicator for target country $j$; 
$M / B_{i}$, the acquirer's market-to-book ratio on announcement day; $I P_{j}$ denotes investor protection; $C A R_{\mathrm{i}}$ is the estimate of cumulative abnormal return for deal $i$ for a three-day window $(-1,+1)$ calculated the event study method outlined above (equation 4); and Pre_Beta $i$ is the acquirer's ex-ante market risk. Table 1 presents a list of all the variables, including their precise definitions and relevant data sources.

\section{(Insert Table 1 here)}

The inclusion of $C A R$ in the probit model is a proxy intended to reflect the market's expectation of deal completion. This enables further testing of hypothesis H1, in addition to the event study results. The inclusion of Pre-Beta controls for acquirers' pre-merger risk. Following Tanna and Yousef (2019), we use the capital asset pricing model (CAPM) to derive an estimate of this variable, which effectively measures the firm's systematic risk (beta before deal). This involves using simple OLS regression of the acquirers' daily stock returns on market returns by invoking the market model with estimation conducted over the period from -110 to -10 working days before announcement day.

\section{Empirical Findings}

\subsection{Event Study Results}

\section{(Insert Table 2 here)}

Table 2 presents the announcement period event study results of the acquirers' abnormal returns and cumulative abnormal returns (CARs) for the overall sample and for sub-samples of completed and cancelled deals. The results uniformly indicate that the abnormal returns (presented for the overall sample only) increase steadily in the days before announcement date, peaking up at one day after announcement, and then declining steadily thereafter. Similarly, the CARs in all cases (both completed and cancelled deals) increase steadily up to one day after announcement and then decline thereafter. All returns are statistically significant for windows of up to six days before and for 10 days after the announcement date. The abnormal returns (AR) for most days prior to day 6 of deal announcement are statistically insignificant but the CARs are mostly significant at 5\% level.

The event study results confirm significant information leakage prior to deal announcements. In essence, merger announcements can be anticipated prior to the official date and therefore 
significant positive abnormal returns can be expected beforehand. Halpern (1983) argues that such leakage may be due to signalling provided by earlier successful bids, or there may be insider trading. Seyhun (1990) argues that leakages may be due to hubris bias which leads to overconfidence and, therefore, overestimation of the merger synergies.

The results also suggest significant post-announcement returns. This arises mainly because new information about the deals that may be revealed after announcement corrects any market reaction that was made on the event date (Martynova and Renneboog, 2011). Hence, when the conditions of the deal become clearer, the market reassesses the quality of the takeover and makes downward corrections to the expected returns.

\subsection{Univariate Tests}

While the results of Table 2 confirm that the CARs are statistically significant and also consistent for the subsamples of completed and failed deals, formal testing of hypothesis $\mathrm{H} 1$ requires that the mean differences of the CARs for the two subsamples are statistically insignificant. Table 3 presents the results of both the parametric t-test and the non-parametric Mann-Whitney U test of the mean differences for different event windows. All results confirm that the mean differences are statistically insignificant, which provides strong evidence that the market reaction is neutral to whether merger deals are eventually completed or not. In another sense, this result confirms the semi-strong form of market efficiency, which holds that markets reflect all publicly available information as revealed in the announcement and/or corporate disclosures before eventual deal completion or termination.

\section{(Insert Table 3 here)}

For preliminary investigation of the hypotheses H2-H5, before formal testing using Probit estimation, we consider univariate tests of the independence of association between the dichotomous classification of completed/failed deals and the specific deal categories under investigation (i.e. target status, payment method, diversification, and acquirer's bidding experience). Since the variable of interest in each case is dichotomous, the appropriate test for the independence of association when the explanatory variable is also dichotomous is the Pearson's chi-squared test. Hence, this test is employed to examine the independence of association in the appropriate subsamples of completed and failed deals, split according to the dichotomous deal categories representing target status (public/private/subsidiary), payment 
method (cash/stock), diversification (DAF, DCI, CBF, CBCI), and acquirer's experience (serial/non-serial bidder).

Table 4 presents the results of the chi-squared tests for each of the categories, showing statistically significant differences between observed and expected frequencies. Here, the test is for the independence of association between the 0/1 classification of the 'dependent' variable (completed/failed deals) and the 0/1 classification of the relevant 'independent' variable, taken in turn (hence $2 \mathrm{x} 2$ ). It is important to bear in mind that the chi-squared test is meant to only assess the significance of the association between the categories rather than uncover causal relationships. The Pearson's chi-squared test measures how well the observed distribution of data fits with the distribution of data that would be otherwise expected (by chance), as if the variables were independent. The statistical significance of Pearson's chi-squared and the phi and Cramer's V tests determines the association between the two relevant categories of variables, i.e. whether the relevant category of the independent variable is associated with the likelihood of a deal being a success or failure. In particular, the positive values of the phi and Cramer's $\mathrm{V}$ tests reveal that the respective categories have a positive association with the likelihood of deal failure/success while the negative values indicate the opposite.

\section{(Insert Table 4 here)}

The results in Table 4 clearly indicate the statistical significance (mostly at the 1 percent level) of the association between the $2 \times 2$ categories of variables, although in most cases these differences, as revealed by the values of the phi and Cramer's V tests, are small. Most notable are the differences in the outcomes that distinguish between target status and diversification. For instance, the overall sample reveals a lower percentage of failed deals involving publicly listed targets (19.3\%) while the corresponding figures for private or subsidiary targets are slightly higher ( $24.6 \%$ and $28.5 \%$ respectively). As the expected percentage of failed deals is $22 \%$ under the independence of association assumption, there is greater likelihood (relative to chance) of deals with non-public targets failing. In contrast, deals involving publicly listed targets are less likely to fail, and these differences in the outcomes between the two categories of deals are reflected in the negative and positive values of the phi and Cramer's V tests. Based on similar reasoning, there is a greater chance of cross-industry and cross-border deals being unsuccessful, relative to domestic and focussed deals.

Interestingly, the results in Table 4 also indicate a negative association between method of payment (cash or stock) and failed deals. Similarly, the association between serial acquirers 
and completed deals is also negative. These results indicate that method of payment and prior bidding experience may be significant factors affecting the probability of deal failure.

\subsection{Probit Estimates}

As explained in section 3.3, the dependent variable in probit estimation is binary $(1 / 0)$, examining the probability of deal failure relative to deals that are completed. The explanatory variables include a set of dummy variables to facilitate testing of the hypotheses $\mathrm{H} 2-\mathrm{H} 5$, as well as a set of control variables to represent firm-specific and country-specific differences. Additionally, we include a proxy for investor expectation of deal completion at the time of announcement, represented by acquirers' three-day CARs $(-1,+1)$, to provide a supplementary test of hypothesis H1. In all regressions, we account for industry, country and year fixed effects, and a minimal set of control variables which include target size (proxied by transaction value), bidder and target country GDP per capita, and acquirers' ex-ante market risk (pre-beta). Furthermore, in some regressions, we include acquirers' market-to-book ratio and bidder size, and control for investor protection (legal origin) and institutional quality in bidder and target countries. The inclusion of these additional controls, despite reducing the sample size, serve to assess the consistency of the results.

Table 5 presents the estimated results of 11 models aiming to analyse the impact of the above M\&A factors on the probability of deal failure. Models 1-7 are estimated using the full sample of completed and failed deals for all countries. Here we progressively add the dummy variables representing the effects of payment method, target status, diversification, and acquirers' prior experience. Model 8-9 include all of these variables (as with models 6-7) and additional control variables, which lowers the sample size for estimation. Models 10 and 11 are estimated using data for deals involving only U.S. acquirers and non-U.S. acquirers, respectively. As confirmed by the values of McFadden's $\mathrm{R}^{2}$ and adjusted $\mathrm{R}^{2}$, the explanatory power of the estimated model increases as more regressions are added.

\section{(Insert Table 5 here)}

Consistent with the univariate tests, the probit results confirm that market reaction at the time of deal announcement (proxied by acquirers' CAR) has, in the full sample, an insignificant impact on the probability of deal failure. Although this finding confirms the neutrality of market reaction to eventual deal outcome, implying support for hypothesis H1, it should be noted that the effect of CAR is statistically significant and negative in Models 9-11, and we 
attribute this statistical significance to the reduced sample size. On the whole, it is difficult to assess the impact of this factor, given that CAR is generally a very imperfect proxy to test this hypothesis in regression.

The results also indicate that cash payment deals reduce the probability of merger failure, while stock payment deals have a mixed or insignificant impact. Thus, payment method does affect the prospect of deal success/failure, and our findings therefore reject hypothesis $\mathrm{H} 2$. A possible explanation of why payment method matters in this regard is due to information asymmetry surrounding bidder/target valuations. Cash payment deals are more favourable for targets as a way of distinguishing high-value bidders from low-value bidders. Thus, as Branch and Yang (2003) argue, cash deals are more likely to be accepted by targets than stock payment deals. However, for U.S. acquirers (model 10), neither of these factors is statistically significant.

With regard to the impact of target status, the results show that the acquisition of public targets increases the chances of deal failure while that of private targets has the opposite effect. This stands in contrast to the findings of the univariate analysis in which the chi-squared tests indicated a relatively higher likelihood of deal success for public targets. However, as noted earlier, the latter reflects the strength of association based on sample proportions and not causal effects. The probit results are more credible in light of theoretical arguments which suggest that public target shareholders are more likely to 'free-ride' on bidder offers while private targets, which tend to have concentrated shareholders, have better negotiating power to ensure deal success. These considerations suggest that, as with payment method, target status affects the probability of deal success/failure, implying rejection of hypothesis H3.

The results also suggest that domestic and focussed deals (DAF) negatively influence the likelihood of deal failure, while diversified deals (here represented by cross-border and crossindustry - CBCI - deals) positively influence this likelihood. ${ }^{4}$ This implies that diversified deals are more likely to fail compared to focussed deals, and this outcome is consistent with the univariate tests. The result is plausible and can be explained by greater uncertainty associated with diversified deals. Evidence shows that greater positive acquirer returns are achieved from such deals relative to domestic and focussed transactions (see e.g. Danbolt and Maciver 2012). Even though synergy gains may be higher from diversification, transaction and monitoring costs associated with such deals may represent a barrier to their successful completion. On the

\footnotetext{
${ }^{4}$ We have omitted other diversification categories (DCI, CBF) from the results as their effects are similar.
} 
whole, the results suggest that diversification affects the probability of deal success/failure, implying rejection of hypothesis $\mathrm{H} 4$.

Turning to the impact of acquirers' bidding experience, the results are mixed in that the impact is positive in some cases and negative in others. In general, acquirers with prior experience ought to have greater expertise in ensuring deal success, although this does not automatically mean that they make efficient decisions. The hubris or over-optimism motives of mergers, which stands in contrast to the rational, synergy-based theories, suggest that serial acquirers tend to destroy rather than improve shareholder value (Roll, 1986). Taking these considerations into account, it is not surprising that acquirers' prior experience has an impact, albeit mixed, on the probability of deal success/failure, implying rejection of hypothesis H5.

As for the effect of the control variables, both target size and acquirers Pre-beta have a negative impact on the probability of deal failure. This implies that larger target size higher pre-merger risk of acquirers increase the chances of deal success, both these effects being consistent with greater synergy gains normally expected from larger or riskier deals. The influence of Prebeta, however, becomes insignificant in after controlling for the effects of market-to-book ration and bidder size whose influences are statistically significant (models 9-11). The negative influence of bidder size is consistent with the expectation of greater synergy from completion, thus reducing the prospect of failure. Larger deals are likely to incur higher costs and require specialist resources (e.g. financial advisors) to which big acquirers are better able to commit, implying greater chances of deal completion. Among the country-level factors, higher GDP per capita for both bidder and target countries decreases the probability of deal failure, as bigger economies have larger markets for corporate control with more financial resources to complete deals. Also, stronger legal and institutional quality in both bidder and target countries reduce the probability of deal failure due to better provisions for property rights protection. On the other hand, stronger investor protection in common law countries has the effect of increasing the prospect of deal failures. Anderson et al. (2009) argue that strong investor protection in a target country affords higher bargaining power to targets, and Hagendorff et al. (2008) argue that investors in relatively unprotected environments may require compensation for these lower governance standards and face a higher risk of expropriation by insiders. These considerations are more likely to adversely affect the chances of deal success and may be one of the reasons for a similarly positive effect of diversified deals.

\section{Conclusion}


This paper investigates whether the likelihood of deal success/failure in M\&A transactions is influenced by four main deal characteristics that typically influence shareholder wealth upon merger announcements: method of payment, target status, diversification, and acquirers' prior bidding experience. Our study makes a contribution by providing robust evidence using a very large and diverse sample of M\&A deals and investigating not only the impact of the aforementioned characteristics on the probability of deal failure, but also weather market reaction at the time of deal announcement reflects an expectation regarding subsequent deal completion. To our best knowledge, such issues have not been previously examined in the literature.

Using a worldwide sample of 45,758 deal announcements, comprising both completed and failed deals, covering 180 countries and 88 industries between the years 1977 and 2012, we carry out both event study and probit regressions to address our objectives. The event study and univariate tests results reveal no significant differences in acquirer returns from successful and unsuccessful deals, suggesting that market reaction upon deal announcements is consistent with the efficient market hypothesis since the returns are not impacted by uncertainty about eventual deal completion or cancellation.

Results from probit regressions suggest that payment method (cash/stock), target status (public/private), diversification (focussed/diversified deals) and acquirers' prior experience (serial/non-serial) are all relevant considerations in ensuring the eventual completion of deals following merger announcements. In particular, focussed deals are more likely to succeed than diversified deals, given greater levels of uncertainty associated with the latter. As diversified deals are more costly, their chances of successful completion are generally lower than focussed deals.

The results also reveal that cash payment deals reduce the probability of deal failure, while the impact of stock payment deals are insignificant. This finding can also be associated with information asymmetry surrounding bidder/target valuation, since cash deals tend to be more favourable for target companies as a way of distinguishing high-value bidders from low-value bidders. With regard to target status, we find that deals involving public targets increase probability of failure compared to deals involving private targets. These findings also make sense in light of theory suggesting that private targets, which tend to have more concentrated shareholders, have more negotiating power to aid in eventual deal completion. As for acquirers' prior experience, the findings are mixed. 
The results of our study offer some practical implications for managers and regulators. The most relevant inference from our analysis can be drawn from the diversification perspective, particularly if viewed in connection with our evidence regarding target status and payment method. While M\&As play an important role in the corporate world by facilitating the reallocation of the merged companies' assets for potential synergy gains, there is persistent 'home country bias' in that most M\&A deals tend to focussed rather than diversified, even though the former may yield relatively lower returns for acquirers. To facilitate greater integration of corporate assets across the world, regulators would be interested in identifying barriers to cross-industry or cross-border consolidation which could lead to improved welfare for all stakeholders. Our results indicate that such integration can be aided by multinationals using cash payments for purchasing private/subsidiary targets abroad, as such deals are more likely to be successfully completed.

\section{References}

Alhenawi, Y., \& Stilwell, M (2017). Value creation and the probability of success in merger and acquisition transactions, Review of Quantitative Finance and Accounting, 49 (4): 1041.

Ali-Yrkko, J., Hyytinen, A., \& Pajarinen, M. (2005) 'Does patenting increase the probability of being acquired? Evidence from cross-border and domestic acquisitions'. Applied Financial Economics 15 (14), 1007-1017.

Anderson, H. D., Marshall, B. R., \& Wales, R. (2009) 'What is the relationship between investor protection legislation and target takeover returns? Evidence from Europe'. Journal of Multinational Financial Management 19 (4), 291-305.

Andrade, G., Mitchell, M., \& Stafford, E. (2001) 'New Evidence and Perspectives on Mergers'. Journal Of Economic Perspectives 15 (2), 103-120.

Baskerville, R. and Hay, D. (2006) The effect of accounting firm mergers on the market for audit services: New Zealand evidence. ABACUS, 42(1), 87-104

Becher, D. A., Cohn, J. B., \& Juergens, J. L. (2015) 'Do Stock Analysts Influence Merger Completion? An Examination of Postmerger Announcement Recommendations'. Management Science 61(10) 2430-2448. 
Beitel, P., Schiereck, D., \& Wahrenburg, M. (2004) 'Explaining M\&A Success in European Banks'. European Financial Management 10 (1), 109-139

Brown, S. J., \& Warner, J. B. (1985) 'Using daily stock returns: The case of event studies'. Journal of financial economics 14 (1), 3-31.

Buch, C. M., \& DeLong, G. (2004) 'Cross-border bank mergers: What lures the rare animal?'. Journal of Banking \& Finance 28 (9), 2077-2102.

Caiazza, S., \& Pozzolo, A. F. (2016), The determinants of failed takeovers in the banking sector: Deal or country characteristics?', Journal of Banking \& Finance, 72 (Supplement), S92-S103.

Choi, J., \& Russell, J. S. (2004) 'Economic gains around mergers and acquisitions in the construction industry of the United States of America'. Canadian Journal of Civil Engineering, 31 (3), 513-525.

Danbolt, J., \& Maciver, G. (2012) 'Cross-Border versus Domestic Acquisitions and the Impact on Shareholder Wealth'. Journal of Business Finance \& Accounting 39 (7-8), 1028-1067.

Faccio, M., McConnell, J. J., \& Stolin, D. (2006) 'Returns to acquirers of listed and unlisted targets'. Journal of Financial and Quantitative Analysis, 41 (1), 197-220.

Focarelli, D., \& Pozzolo, A. F. (2001) 'The patterns of cross-border bank mergers and shareholdings in OECD countries'. Journal of banking \& Finance 25 (12), 2305-2337.

Focarelli, D., Pozzolo, A. F., \& Salleo, C. (2008) 'Focus Vs. Diversification in The Financial Industry: The Effect Of M\&As On Systematic Risk'. Journal of Banking and Finance 08-2142.

Fuller, K., Netter, J., \& Stegemoller, M. (2002) 'What do returns to acquiring firms tell us? Evidence from firms that make many acquisitions'. Journal of Finance 57 (4), 1763-1793.

Gonzalez, P., Vasconcellos, G. M., Kish, R. J., \& Kramer, J. K. (1997) ‘Cross-border mergers and acquisitions: maximizing the value of the firm'. Applied Financial Economics 7 (3), 295305.

Hagendorff, J., Collins, M., \& Keasey, K. (2008) 'Investor protection and the value effects of bank merger announcements in Europe and the US'. Journal of Banking \& Finance 32 (7), 1333-1348. 
Hannan, T. H., \& Pilloff, S. J. (2009) 'Acquisition targets and motives in the banking industry'. Journal of Money, Credit and Banking 41 (6), 1167-1187.

Hensher, D.A. and Jones, S. (2007) Forecasting corporate bankruptcy: optimising the performance of the mixed logit model. ABACUS, 43(2), 241-264

Jaffe, J., Jindra, J., Pedersen, D., \& Voetmann, T. (2015) 'Returns to Acquirers of Public and Subsidiary Targets'. Journal of Corporate Finance 31 (2015) 246-270

Kohers, N. and Kohers, T. (2000) 'The value creation potential of high-tech mergers'. Financial Analysts Journal 40-48.

Long, J. S., \& Freese, J. (2006) Regression models for categorical dependent variables using Stata. Stata press.

MacKinlay, A. C. (1997) 'Event studies in Economics and Finance'. Journal of Economic Literature 35 (1), 13-39.

Mai, L., van Ness, R., \& van Ness, B. (2009). Short sales around M\&A announcements. Journal of Financial Economic Policy, 1(2), 177-197.

Malmendier, U., Opp, M. M., \& Saidi, F. (2016) 'Target Revaluation after Failed Takeover Attempts-Cash versus Stock’. Journal of Financial Economics 119 (1), 92-106.

Mangold, N, \& Lippok, K. (2008) 'The Effect Of Cross-Border Mergers And Acquisitions On Shareholder Wealth: Evidence From Germany'. Journal of International Business \& Economics 8 (3), 29-54

Martynova, M., \& Renneboog, L. (2011) 'The Performance of the European Market for Corporate Control: Evidence from the Fifth Takeover Wave'. European Financial Management 17 (2), 208-259.

Moeller, S. B., \& Schlingemann, F. P. (2005) 'Global Diversification and Bidder Gains: A Comparison between Cross-Border and Domestic Acquisitions'. Journal Of Banking And Finance 29 (3), 533-564.

Moeller, S. B., Schlingemann, F. P., \& Stulz, R. M. (2004) 'Firm size and the gains from acquisitions'. Journal of Financial Economics 73 (2), 201-228. 
Mulherin, J. H. and Boone, A. L. (2000) 'Comparing acquisitions and divestitures'. Journal of Corporate Finance 6, 117-39.

Officer, M.S., Poulsen, A.B. \& Stegemoller, M. (2009) 'Target-firm information asymmetry and acquirer returns'. Review of Finance 13 (3), 467-493.

Pasiouras, F., Tanna, S., \& Gaganis, C. (2011) 'What drives acquisitions in the EU banking industry? The role of bank regulation and supervision framework, bank specific and market specific factors'. Financial Markets, Institutions \& Instruments 20 (2), 29-77.

Peat, M. (2007) Factors affecting the probability of bankruptcy: a managerial decision based approach. ABACUS, 43(3), $303-325$

Powell, R. G. (1997) 'Modelling takeover likelihood'. Journal of Business Finance \& Accounting 24 (7), 1009-1030.

Raj, M., \& Uddin, M. (2013) 'Do Bidders Gain in Related Acquisitions? Some Evidence from UK'. International Journal Of Economics And Finance 5 (1), 150-165.

Rani, N., Yadav, S. S., \& Jain, P. K. (2014) 'Impact of Domestic and Cross-Border Acquisitions on Acquirer Shareholders' Wealth: Empirical Evidence from Indian Corporate'. International Journal of Business and Management 9 (3), 88.

Roll, R. (1986) The hubris hypothesis of corporate takeovers. Journal of Business 59 (2), 197 216.

Rossi, S., \& Volpin, P. F. (2004) 'Cross-country determinants of mergers and acquisitions. Journal of Financial Economics 74 (2), 277-304.

Tang, T. (2015) 'Bidder's Gain: Evidence from Termination Returns'. International Review of Finance 15 (4), 457-487.

Tanna, S., \& Yousef, I. (2019), 'Mergers and Acquisitions: Implications for Acquirers' Market Risk', Managerial Finance, 45 (4), 545-562.

Wheelock, D. C., \& Wilson, P. W. (2004) 'Consolidation in US banking: Which banks engage in mergers?'. Review of Financial Economics 13 (1), 7-39. 
$D A F_{\mathrm{i}}$ : dummy variable equal to 1 for deal $i$ if the acquirer and target are located in the same country and operate in the same industry, 0 otherwise.

$D C I_{\mathrm{i}}$ : dummy variable equal to 1 for announcement $i$ if the acquirer and target are located in the same country but operate in different industries (according to the initial two digits of their four-digit SIC codes), 0 otherwise.

$C B F_{\mathrm{i}}$ : dummy variable equal to 1 for announcement $i$ if the acquirer and target operate in the same industry but are located in different countries, 0 otherwise.

$C B C I_{\mathrm{i}}$ : dummy variable equal to 1 for announcement $i$ if the acquirer and target are located in different countries and operate in different industries (according to the initial two digits of their four-digit SIC codes), 0 otherwise.

$\mathrm{CSH}_{\mathrm{i}}$ : dummy variable equal to 1 for announcement $i$ if the acquirer paid by cash only, and 0 otherwise.

$S T C_{\mathrm{i}}$ : dummy variable equal to 1 for announcement $i$ if the acquirer paid by stock only, 0 otherwise.

$P u b_{\mathrm{i}}$ : dummy variable equal to 1 for announcement $i$ if the target is a public company, 0 otherwise.

$\operatorname{Priv}_{\mathrm{i}}$ : dummy variable equal to 1 for announcement $i$ if the target is a private company, 0 otherwise.

$\operatorname{Subs}_{\mathrm{i}}$ : dummy variable equal to 1 for announcement $i$ if the target is a subsidiary company, 0 otherwise.

$\operatorname{Exp}_{\mathrm{i}}$ : cumulative number of takeovers by the same acquirer during a three-year period. In regressions, for brevity, we only present results for experience for the three-year period, although univariate analysis we present results for three-year and five-year periods.

$V T_{\mathrm{i}}$ : logarithm of value of transactions for deal $i$ (in US \$mil, i.e. total value of consideration paid by the acquirer excluding fees and expenses) to represent target size. Source: Datastream

GDP $_{\mathrm{j}}$ : logarithm of GDP per capita of country $j$, which includes both target and acquirer countries. Source: Datastream

$M / B_{\mathrm{i}}$ : acquirer's market-to-book ratio on announcement day. Source: Datastream

$A S_{\mathrm{i}}$ : logarithm of market value in US \$mil of acquirer $i$ (calculated by multiplying the total number of bidder shares times its stock price four weeks prior to the announcement date), to represent Acquirer's size. Source: Datastream

$L I Q_{\mathrm{j}}$ : quality of institutions represented by the legal institutional quality indicator. (Source: Kuncic 2014)

$I P_{\mathrm{j}}$ : dummy variable equal to 1 if the target is located in a country that applies common law (investor protection), 0 otherwise. Source: ?

$C A R_{\mathrm{i}}$ : cumulative abnormal return for deal $i$ for a three-day window $(-1,+1)$, calculated using an event study method and market model. Source: Authors calculation using equation 4.

Pre_Beta $_{i}$ : acquirer's 'beta before deal' calculated from -110 to -11 working days before the announcement day. Source: Authors calculation (Tanna and Yousef, 2019)

\section{Table 2: Announcement Period Returns for Acquirers}

Abnormal returns (ARs) and cumulative abnormal returns (CARs) have been calculated using the market model, i.e. by subtracting the actual returns made during the event window from the expected returns based on the projections of the market model during the event period. The AR results are presented for event windows up to ten days before and after the announcement date $(-10,+10)$. Deal announcement date is day 0 . The sample consists of 46,758 initial bids announced in 180 countries covering 88 sub-industries over the period 19772012, where 36,489 deals were completed and 10,269 were cancelled. The symbols ****, **, and * denote statistical significance at the levels of $1 \%, 5 \%$, and $10 \%$, respectively.

\begin{tabular}{|c|c|c|c|c|}
\hline & \multicolumn{2}{|c|}{ All Sample $(n=46,758)$} & $\begin{array}{c}\text { Successful Deals, } \\
n=36,489\end{array}$ & $\begin{array}{c}\text { Failed Deals, } \\
n=10,269\end{array}$ \\
\hline Day & ARs \% & CARs\% & CARs $\%$ & CARs \% \\
\hline-10 & 0.03 & 0.03 & 0.01 & 0.09 \\
\hline-9 & $0.07 * * *$ & $0.1 * * *$ & $0.07 * *$ & $0.2 * *$ \\
\hline-8 & 0.02 & $0.12 * * *$ & $0.11 * * *$ & 0.14 \\
\hline-7 & 0.02 & $0.14 * * *$ & $0.12 * *$ & $0.22 *$ \\
\hline-6 & $0.08 * * *$ & $0.22 * * *$ & $0.17 * * *$ & $0.39 * * *$ \\
\hline-5 & $0.12 * * *$ & $0.34 * * *$ & $0.26 * * *$ & $0.63 * * *$ \\
\hline-4 & $0.11 * * *$ & $0.45 * * *$ & $0.37 * * *$ & $0.75 * * *$ \\
\hline-3 & $0.13 * * *$ & $0.59 * * *$ & $0.49 * * *$ & $0.92 * * *$ \\
\hline-2 & $0.18 * * *$ & $0.76 * * *$ & $0.64 * * *$ & $1.2 * * *$ \\
\hline-1 & $0.31 * * *$ & $1.07 * * *$ & $0.87 * * *$ & $1.79 * * *$ \\
\hline $\mathbf{0}$ & $0.83 * * *$ & $1.9 * * *$ & $1.66 * * *$ & $2.75 * * *$ \\
\hline 1 & $0.44 * * *$ & $2.34 * * *$ & $2.13 * * *$ & $3.06^{* * *}$ \\
\hline 2 & $-0.03 * * *$ & $2.31 * * *$ & $2.16^{* * *}$ & $2.82 * * *$ \\
\hline
\end{tabular}




\begin{tabular}{ccccc}
3 & $-0.12 * * *$ & $2.18 * * *$ & $2.07 * * *$ & $2.59 * * *$ \\
4 & $-0.12 * * *$ & $2.06 * * *$ & $1.99 * * *$ & $2.33 * * *$ \\
5 & $-0.12 * * *$ & $1.94 * * *$ & $1.92 * * *$ & $2.04 * * *$ \\
6 & $-0.09 * * *$ & $1.85 * * *$ & $1.81 * * *$ & $2.0 * * *$ \\
7 & $-0.1 * * *$ & $1.75 * * *$ & $1.75 * * *$ & $1.75 * * *$ \\
8 & $-0.1 * * *$ & $1.65 * * *$ & $1.69 * * *$ & $1.53 * * *$ \\
9 & $-0.13 * * *$ & $1.52 * * *$ & $1.57 * * *$ & $1.34 * * *$ \\
10 & $-0.11 * * *$ & $1.4 * * *$ & $1.5 * * *$ & $1.07 * * *$ \\
\hline
\end{tabular}

\section{Table 3: Tests of mean differences in CARs: Completed versus Failed Deals.}

An independent samples t-test and a Mann-Whitney U Test are employed to compare the differences in the CARs of completed and terminated deals. Since the CARs are not usually normally distributed, both the t-test and the $U$ test are applied for consistency checks. Tests are shown for event windows of: $(-5,+5),(-3,+3),(-2,+2)$, and $(-1,+1)$. Of the overall sample of 46,789 deals, 36,489 were completed, and 10,269 were cancelled. 'Yes'/'No' indicates the number of deals completed/cancelled. The symbols $* * * *, * *$, and * denote statistical significance at the levels of $1 \%, 5 \%$, and $10 \%$, respectively.

\begin{tabular}{|c|c|c|c|c|c|c|c|c|c|}
\hline & \multirow[b]{2}{*}{ Completed } & \multirow[b]{2}{*}{$\mathrm{N}$} & \multicolumn{4}{|c|}{ Independent Samples t-Test } & \multicolumn{3}{|c|}{ Mann-Whitney U } \\
\hline & & & $\begin{array}{c}\text { Mean } \\
\%\end{array}$ & Mean Dif. & $\mathrm{t}$ & p-value & Mean Rank & $\mathrm{Z}$ & p-value \\
\hline \multirow{2}{*}{ CARs $(-5,+5)$} & Yes & 36489 & 1.712 & \multirow{2}{*}{.148} & \multirow{2}{*}{.641} & \multirow{2}{*}{.522} & 23465 & \multirow{2}{*}{-1.573} & \multirow{2}{*}{.170} \\
\hline & No & 10269 & 1.564 & & & & 23077 & & \\
\hline \multirow{2}{*}{ CARs $(-3,+3)$} & Yes & 36489 & 1.672 & \multirow{2}{*}{-.092} & \multirow{2}{*}{-.461} & \multirow{2}{*}{.645} & 23423 & \multirow{2}{*}{-1.311} & \multirow{2}{*}{.190} \\
\hline & No & 10269 & 1.764 & & & & 23225 & & \\
\hline CARs $(-2,+2)$ & Yes & 36489 & 1.642 & -.175 & \multirow{2}{*}{-.994} & .320 & 23391 & \multirow{2}{*}{-.357} & .721 \\
\hline \multirow[b]{2}{*}{ CARs $(-1,+1)$} & $\begin{array}{l}\text { NO } \\
\text { Yes }\end{array}$ & $\begin{array}{l}10209 \\
36489\end{array}$ & $\begin{array}{l}1.811 \\
1.473\end{array}$ & \multirow[b]{2}{*}{-.330} & & \multirow[b]{2}{*}{.133} & 23337 & & \multirow[b]{2}{*}{.529} \\
\hline & No & 10269 & 1.803 & & -1.134 & & 23453 & -.629 & \\
\hline
\end{tabular}

Table 4: Pearson's Chi-Squared Tests for Deal Categories.

This table shows the results of Pearson's chi-squared test and the phi and Cramer's V statistics which have been used to assess the independence of the association between two groups of categorical variables (hence $2 \times 2$ ). The first categorical (dependent) variable distinguishes between failed (1) and completed (0) deals. The second categorical variable is one of the dichotomous (1/0) independent variables listed in the table. These variables are 1) public: when the bidder acquires public target. 2) Priv: when the bidder acquires private target. 3) Sub.: when the bidder acquires an unlisted subsidiary target. (4) Cash-only: when the bidder used cash only for payment of the deal. (5) Stock-only: when the bidder used stock only as payment method. 6) Domestic and focussed deals (DAF): bidder and target are located in the same country and operate in the same industry. 7) Domestic cross-industry deals (DCI): bidder and target are located in the same country but operate in different industries (according to the initial two digits of their four-digit SIC codes). 8) Cross-border focussed deals $(\mathrm{CBF})$ : bidder and target operate in the same industry but are located in different countries. 9) Cross-border cross-industry deals (CBCI): bidder and target are located in different countries and operate in different industries. 10) Exp. 5Y: when the same bidder has two or more completed deals over the five preceding years. 11) Exp. 3Y: when the same bidder has two or more completed deals over the three preceding years. In each of these categories, Yes denotes failed deals, No otherwise (completed). The symbols ****,**, and * denote statistical significance at the levels of $1 \%$, $5 \%$, and $10 \%$, respectively.

\begin{tabular}{|c|c|c|c|c|c|c|c|c|c|c|c|c|}
\hline \multirow[b]{3}{*}{ Failed Deal } & \multicolumn{8}{|c|}{ Pearson Chi-square frequencies } & \multicolumn{4}{|c|}{ Chi-Square statistics } \\
\hline & \multicolumn{2}{|c|}{ Actual Count } & \multicolumn{2}{|c|}{$\begin{array}{c}\text { Expected } \\
\text { Count }\end{array}$} & \multicolumn{2}{|c|}{$\begin{array}{c}\% \text { within } \mathrm{X} \\
\text { (Actual) }\end{array}$} & \multicolumn{2}{|c|}{$\%$ within $\mathrm{X}$ (Expected) } & \multirow[t]{2}{*}{ Value } & \multirow[t]{2}{*}{ p-value } & \multirow{2}{*}{$\begin{array}{c}\text { Phi \& } \\
\text { Cramer's } \\
\text { V }\end{array}$} & \multirow{2}{*}{$\mathrm{p}$-value } \\
\hline & Yes & No & Yes & No & Yes & No & Yes & No & & & & \\
\hline Public & 2698 & 11315 & 3078 & 10935 & $19.3 \%$ & $80.7 \%$ & $22 \%$ & $78 \%$ & 85.65 & $.000 * * *$ & -.043 & $.000 * * *$ \\
\hline Priv. & 5413 & 16609 & 4836 & 17186 & $24.6 \%$ & $75.4 \%$ & $22 \%$ & $78 \%$ & 52.41 & $.000 * * *$ & .033 & $.000 * * *$ \\
\hline Sub. & 3058 & 7665 & 2355 & 8368 & $28.5 \%$ & $71.5 \%$ & $22 \%$ & $78 \%$ & 348.95 & $.000 * * *$ & .086 & $.000 * * *$ \\
\hline Cash Only & 2591 & 10668 & 2912 & 10347 & $19.5 \%$ & $80.5 \%$ & $22 \%$ & $78 \%$ & 63.27 & $.000 * * *$ & -.037 & $.000 * * *$ \\
\hline Stock Only & 2371 & 9310 & 2565 & 9116 & $20.3 \%$ & $79.7 \%$ & $22 \%$ & $78 \%$ & 25.16 & $.000 * * *$ & -.023 & $.000 * * *$ \\
\hline DAF & 3708 & 14762 & 4056 & 14414 & $20.1 \%$ & $79.9 \%$ & $22 \%$ & $78 \%$ & 63.38 & $.000 * * *$ & -.037 & $.000 * * *$ \\
\hline DCI & 4041 & 13024 & 3748 & 13317 & $23.7 \%$ & $76.3 \%$ & $22 \%$ & $78 \%$ & 46.28 & $.000 * * *$ & .031 & $.000 * * *$ \\
\hline $\mathrm{CBF}$ & 1297 & 4924 & 1366 & 4855 & $20.8 \%$ & $79.2 \%$ & $22 \%$ & $78 \%$ & 5.19 & $.023 * *$ & -.011 & $.023^{* *}$ \\
\hline CBCI & 1223 & 3779 & 1099 & 3903 & $24.5 \%$ & $75.5 \%$ & $22 \%$ & $78 \%$ & 20.23 & $.000 * * *$ & .021 & $.000 * * *$ \\
\hline Exp. 5-Y & 5058 & 20005 & 5504 & 19559 & $20.2 \%$ & $79.8 \%$ & $22 \%$ & $78 \%$ & 99.96 & $.000 * * *$ & -.046 & $.000 * * *$ \\
\hline
\end{tabular}


Table 5: Probit Estimates for Probability of Deal Failure

The dependent variable is binary, representing the probability of deal failure/success (coded as ' 0 ' for successful deals and ' 1 ' for failed deals). The independent variables are: (1) logarithm of transaction values. (2) logarithm of the GDP per capita of the target country. (3) Domestic and focussed deals (DAF): bidder and target are located in the same country and operate in the same industry. (4) Cross-border cross-industry deals (CBCI): bidder and target are located in different countries and operate in different industries. (5) Cash-only: when the bidder used cash only for payment of the deal. (6) Stock-only: when the bidder used stock only as payment method; (6) public: when the bidder acquires public target. (7) Priv: when the bidder acquires private target. (8) 'Exp. $3 Y^{\prime}$ is the cumulative number of deals by the same acquirer during the preceding three years. (9) Legal Ins Quality (Target) : proxy for institutional environment. (10) Common Law : proxy for investor protection. (11) CARs $(-1,+1)$ : acquirers' three-day CARs $(-1,+1)$. $(12)$ Pre-Beta: acquirer's 'beta before deal' calculated from -110 to -10 working days before the announcement day; (12) Bidder size: the acquirer's market capitalisation four weeks prior to announcement day. Models 1-9 are estimated using available data for all countries. Models 10 and 11 are estimated on data available for deals involving U.S. acquirers and non-U.S. acquirers only, respectively. Estimation is by maximum likelihood with p-values shown in parentheses. All estimations include year and industry effects, as well as country effects where possible (subject to avoidance of multicollinearity).

\begin{tabular}{|c|c|c|c|c|c|c|c|c|c|c|c|}
\hline Probit & (1) & (2) & (3) & (4) & (5) & (6) & (7) & $(8)$ & (9) & $(10)$ & $(11)$ \\
\hline No. obs & 45631 & 45631 & 45631 & 45631 & 45631 & 45631 & 45631 & 39393 & 25938 & 10816 & 15122 \\
\hline McFadden R2 & 0.062 & 0.060 & 0.062 & 0.065 & 0.067 & 0.068 & 0.074 & 0.103 & 0.127 & 0.078 & 0.117 \\
\hline Adjusted R2 & 0.062 & 0.060 & 0.062 & 0.065 & 0.067 & 0.068 & 0.073 & 0.102 & 0.125 & 0.073 & 0.115 \\
\hline \multirow[t]{2}{*}{ Constant } & 2.128 & 2.106 & 2.128 & 2.246 & 2.247 & 2.305 & 2.102 & 2.037 & 2.572 & 1.437 & 2.073 \\
\hline & $(0.000)$ & $(0.000)$ & $(0.000)$ & $(0.000)$ & $(0.000)$ & $(0.000)$ & $(0.000)$ & $(0.000)$ & $(0.000)$ & $(0.000)$ & $(0.000)$ \\
\hline \multirow[t]{2}{*}{ Value of Trans. } & -0.048 & -0.048 & -0.047 & -0.068 & -0.067 & -0.071 & -0.071 & -0.080 & -0.025 & 0.048 & -0.040 \\
\hline & $(0.000)$ & $(0.000)$ & $(0.000)$ & $(0.000)$ & $(0.000)$ & $(0.000)$ & $(0.000)$ & $(0.000)$ & $(0.000)$ & $(0.000)$ & $(0.000)$ \\
\hline \multirow[t]{2}{*}{ GDP (Target) } & -0.559 & -0.567 & -0.556 & -0.576 & -0.545 & -0.557 & -0.559 & -0.502 & -0.578 & -0.362 & -0.483 \\
\hline & $(0.000)$ & $(0.000)$ & $(0.000)$ & $(0.000)$ & $(0.000)$ & $(0.000)$ & $(0.000)$ & $(0.000)$ & $(0.000)$ & $(0.000)$ & $(0.000)$ \\
\hline \multirow[t]{2}{*}{ DAF } & & & -0.031 & -0.046 & -0.040 & -0.044 & -0.063 & -0.053 & -0.051 & -0.091 & -0.011 \\
\hline & & & $(0.035)$ & $(0.002)$ & $(0.007)$ & $(0.003)$ & $(0.000)$ & $(0.001)$ & $(0.012)$ & $(0.010)$ & $(0.670)$ \\
\hline \multirow[t]{2}{*}{ CBCI } & & & 0.059 & 0.063 & 0.060 & 0.066 & 0.057 & 0.086 & 0.123 & 0.042 & 0.089 \\
\hline & & & $(0.006)$ & $(0.004)$ & $(0.006)$ & $(0.004)$ & $(0.007)$ & $(0.002)$ & $(0.001)$ & $(0.068)$ & $(0.013)$ \\
\hline \multirow[t]{2}{*}{ Cash-Only } & -0.148 & & -0.149 & -0.166 & -0.166 & -0.168 & -0.158 & -0.174 & -0.104 & -0.031 & -0.119 \\
\hline & $(0.000)$ & & $(0.000)$ & $(0.000)$ & $(0.000)$ & $(0.000)$ & $(0.000)$ & $(0.000)$ & $(0.000)$ & $(0.473)$ & $(0.000)$ \\
\hline \multirow[t]{2}{*}{ Stock-Only } & & 0.055 & 0.005 & -0.018 & 0.004 & -0.002 & -0.006 & 0.037 & -0.072 & -0.024 & -0.053 \\
\hline & & $(0.001)$ & $(0.756)$ & $(0.295)$ & $(0.802)$ & $(0.919)$ & $(0.736)$ & $(0.047)$ & $(0.003)$ & $(0.535)$ & $(0.102)$ \\
\hline \multirow[t]{2}{*}{ Public } & & & & 0.219 & & 0.103 & 0.082 & 0.218 & 0.180 & 0.441 & 0.038 \\
\hline & & & & $(0.000)$ & & $(0.000)$ & $(0.000)$ & $(0.000)$ & $(0.000)$ & $(0.000)$ & $(0.302)$ \\
\hline \multirow[t]{2}{*}{ Private } & & & & & -0.224 & -0.173 & -0.182 & -0.098 & -0.159 & -0.085 & -0.102 \\
\hline & & & & & $(0.000)$ & $(0.000)$ & $(0.000)$ & $(0.000)$ & $(0.000)$ & $(0.145)$ & $(0.000)$ \\
\hline \multirow[t]{2}{*}{ Exp. 3-Y } & & & & & & -0.018 & -0.018 & -0.016 & 0.012 & 0.021 & 0.003 \\
\hline & & & & & & $(0.000)$ & $(0.000)$ & $(0.000)$ & $(0.009)$ & $(0.001)$ & $(0.715)$ \\
\hline \multirow[t]{2}{*}{ Legal Ins Quality (Target) } & & & & & & & & -0.293 & -0.284 & -0.257 & -0.283 \\
\hline & & & & & & & & $(0.000)$ & $(0.000)$ & $(0.000)$ & $(0.000)$ \\
\hline \multirow[t]{2}{*}{ Common Law (Target) } & & & & & & & 0.284 & 0.292 & 0.268 & -0.068 & 0.366 \\
\hline & & & & & & & $(0.000)$ & $(0.000)$ & $(0.000)$ & $(0.416)$ & $(0.000)$ \\
\hline \multirow[t]{2}{*}{ CARs $(-1,+1)$} & -0.047 & -0.037 & -0.050 & -0.011 & -0.023 & -0.017 & -0.023 & -0.043 & -0.303 & -0.308 & -0.260 \\
\hline & $(0.363)$ & $(0.468)$ & $(0.327)$ & $(0.835)$ & $(0.652)$ & $(0.748)$ & $(0.649)$ & $(0.439)$ & $(0.000)$ & $(0.009)$ & $(0.015)$ \\
\hline \multirow[t]{2}{*}{ Pre-Beta } & -0.032 & -0.034 & -0.032 & -0.030 & -0.033 & -0.029 & -0.028 & -0.022 & 0.012 & -0.020 & 0.063 \\
\hline & $(0.000)$ & $(0.000)$ & $(0.000)$ & $(0.000)$ & $(0.000)$ & $(0.001)$ & $(0.001)$ & $(0.016)$ & $(0.336)$ & $(0.291)$ & $(0.000)$ \\
\hline \multirow[t]{2}{*}{ M/B Ratio } & & & & & & & & & 0.000 & 0.001 & 0.000 \\
\hline & & & & & & & & & $(0.659)$ & $(0.662)$ & $(0.596)$ \\
\hline \multirow[t]{2}{*}{ Bidder Size } & & & & & & & & & -0.091 & -0.158 & -0.063 \\
\hline & & & & & & & & & $(0.000)$ & $(0.000)$ & $(0.000)$ \\
\hline Country Dumm. & Yes & Yes & Yes & Yes & Yes & Yes & Yes & Yes & Yes & No & Yes \\
\hline Industry Dumm. & Yes & Yes & Yes & Yes & Yes & Yes & Yes & Yes & Yes & Yes & Yes \\
\hline Year Dummies & Yes & Yes & Yes & Yes & Yes & Yes & Yes & Yes & Yes & Yes & Yes \\
\hline
\end{tabular}


Appendix 1: M\&A Deals According to Country of Target

\begin{tabular}{|c|c|c|c|c|c|c|c|c|}
\hline \multicolumn{9}{|c|}{ Target Country } \\
\hline Country & No & $\%$ & Country & No & $\%$ & Country & No & $\%$ \\
\hline Albania & 5 & .011 & Greenland & 1 & .002 & Panama & 18 & 0.038 \\
\hline Algeria & 4 & .009 & Guam & 1 & .002 & $\begin{array}{l}\text { Papua N } \\
\text { Guinea }\end{array}$ & 23 & 0.049 \\
\hline Antigua & 5 & .011 & Guatemala & 10 & .021 & Paraguay & 4 & 0.009 \\
\hline Argentina & 137 & .293 & Guernsey & 16 & .034 & Peru & 91 & 0.195 \\
\hline Armenia & 5 & .011 & Guyana & 10 & .021 & Philippines & 179 & 0.383 \\
\hline Aruba & 1 & .002 & Haiti & 1 & .002 & Poland & 261 & 0.558 \\
\hline Australia & 2089 & 4.468 & Honduras & 1 & .002 & Portugal & 89 & 0.190 \\
\hline Austria & 65 & .139 & Hong Kong & 914 & 1.955 & Puerto Rico & 18 & 0.038 \\
\hline Bahamas & 8 & .017 & Hungary & 33 & .071 & Qatar & 7 & 0.015 \\
\hline Bahrain & 1 & .002 & Iceland & 15 & .032 & Rep of Congo & 7 & 0.015 \\
\hline Bangladesh & 6 & .013 & India & 455 & .973 & Reunion & 1 & 0.002 \\
\hline Barbados & 7 & .015 & Indonesia & 287 & .614 & Romania & 52 & 0.111 \\
\hline Belarus & 5 & .011 & Iran & 1 & .002 & Russian Fed & 239 & 0.511 \\
\hline Belgium & 160 & .342 & Iraq & 7 & .015 & Rwanda & 1 & 0.002 \\
\hline Belize & 4 & .009 & IrelandRep & 154 & .329 & Saudi Arabia & 20 & 0.043 \\
\hline Bermuda & 46 & .098 & Isle of Man & 14 & .030 & Senegal & 1 & 0.002 \\
\hline Bolivia & 10 & .021 & Israel & 192 & .411 & Serbia & 9 & 0.019 \\
\hline Bosnia & 7 & .015 & Italy & 409 & .875 & $\begin{array}{l}\text { Serbia \& } \\
\text { Mont. }\end{array}$ & 10 & 0.021 \\
\hline Botswana & 3 & .006 & Jamaica & 4 & .009 & Seychelles & 4 & 0.009 \\
\hline Brazil & 547 & 1.170 & Japan & 2968 & 6.348 & Sierra Leone & 2 & 0.004 \\
\hline British Virgin & 84 & .180 & Jersey & 11 & .024 & Singapore & 489 & 1.046 \\
\hline Brunei & 3 & .006 & Jordan & 12 & .026 & Slovak Rep & 15 & 0.032 \\
\hline Bulgaria & 31 & .066 & Kazakhstan & 24 & .051 & Slovenia & 20 & 0.043 \\
\hline Burkina Faso & 5 & .011 & Kenya & 3 & .006 & Solomon Is & 1 & 0.002 \\
\hline Burundi & 1 & .002 & Kuwait & 27 & .058 & South Africa & 445 & 0.952 \\
\hline Cambodia & 6 & .013 & Kyrgyzstan & 17 & .036 & South Korea & 1222 & 2.613 \\
\hline Cameroon & 2 & .004 & Laos & 6 & .013 & Spain & 383 & 0.819 \\
\hline Canada & 3127 & 6.688 & Latvia & 7 & .015 & Sri Lanka & 10 & 0.021 \\
\hline Cape Verde & 1 & .002 & Lebanon & 5 & .011 & Sudan & 3 & 0.006 \\
\hline $\begin{array}{l}\text { Cayman } \\
\text { Islands }\end{array}$ & 14 & .030 & Liberia & 2 & .004 & Surinam & 1 & 0.002 \\
\hline Chile & 135 & .289 & Lithuania & 21 & .045 & Swaziland & 2 & 0.004 \\
\hline China & 3087 & 6.602 & Luxembourg & 34 & .073 & Sweden & 477 & 1.020 \\
\hline Colombia & 86 & .184 & Macau & 4 & .009 & Switzerland & 194 & 0.415 \\
\hline Costa Rica & 6 & .013 & Macedonia & 6 & .013 & Syria & 1 & 0.002 \\
\hline Croatia & 23 & .049 & Madagascar & 2 & .004 & Taiwan & 269 & 0.575 \\
\hline Cuba & 1 & .002 & Malaysia & 1190 & 2.545 & Tajikistan & 3 & 0.006 \\
\hline Cyprus & 40 & .086 & Mali & 6 & .013 & Tanzania & 9 & 0.019 \\
\hline $\begin{array}{l}\text { Czech } \\
\text { Republic }\end{array}$ & 73 & .156 & Malta & 7 & .015 & Thailand & 287 & 0.614 \\
\hline Czechoslovakia & 3 & .006 & Marshall Is & 2 & .004 & Togo & 1 & 0.002 \\
\hline $\begin{array}{l}\text { Dem Rep } \\
\text { Congo }\end{array}$ & 3 & .006 & Mauritania & 3 & .006 & Trinidad\&Tob & 8 & 0.017 \\
\hline
\end{tabular}




\begin{tabular}{lcclcclcc} 
Denmark & 166 & .355 & Mauritius & 10 & .021 & Tunisia & 4 & 0.009 \\
Dominican Rep & 9 & .019 & Mexico & 168 & .359 & Turkey & 125 & 0.267 \\
Ecuador & 14 & .030 & Moldova & 3 & .006 & Turkmenistan & 2 & 0.004 \\
Egypt & 42 & .090 & Monaco & 9 & .019 & Turks/Caicos & 1 & 0.002 \\
El Salvador & 3 & .006 & Mongolia & 16 & .034 & Uganda & 3 & 0.006 \\
Eritrea & 1 & .002 & Montenegro & 2 & .004 & Ukraine & 52 & 0.111 \\
Estonia & 13 & .028 & Morocco & 11 & .024 & United & 4376 & 9.359 \\
Ethiopia & 3 & .006 & Mozambique & 7 & .015 & United States & 17376 & 37.162 \\
Falkland Is & 2 & .004 & Namibia & 19 & .041 & Uruguay & 12 & 0.026 \\
Faroe Islands & 1 & .002 & Nepal & 1 & .002 & Utd Arab Em & 27 & 0.058 \\
Fiji & 6 & .013 & Neth & 4 & .009 & Uzbekistan & 3 & 0.006 \\
Finland & 227 & .485 & Netherlands & 327 & .699 & Vanuatu & 1 & 0.002 \\
Fr Polynesia & 1 & .002 & New & 148 & .317 & Venezuela & 25 & 0.053 \\
France & 737 & 1.576 & Nicaragua & 11 & .024 & Vietnam & 39 & 0.083 \\
Gabon & 1 & .002 & Nigeria & 11 & .024 & Western & 1 & 0.002 \\
Georgia & 5 & .011 & Niue & 2 & .004 & Yemen & 1 & 0.002 \\
Germany & 606 & 1.296 & North Korea & 2 & .004 & Yugoslavia & 5 & 0.011 \\
Ghana & 11 & .024 & Norway & 341 & .729 & Zambia & 9 & 0.019 \\
Gibraltar & 2 & .004 & Oman & 6 & .013 & Zimbabwe & 5 & 0.011 \\
Greece & 126 & .269 & Pakistan & 13 & .028 & Total & 46758 & 100 \\
\hline & & & & & & & \\
\hline
\end{tabular}


Appendix 2: M\&A Deals According to Country of Acquirer

\begin{tabular}{|c|c|c|c|c|c|c|c|c|}
\hline \multicolumn{9}{|c|}{ Acquirer Country } \\
\hline Country & No & $\%$ & Country & No & $\%$ & Country & No & $\%$ \\
\hline Argentina & 51 & .109 & Hong Kong & 1089 & 2.329 & Papua N Guinea & 5 & .011 \\
\hline Australia & 2168 & 4.637 & Hungary & 28 & 0.060 & Peru & 32 & .068 \\
\hline Austria & 73 & .156 & Iceland & 35 & 0.075 & Philippines & 159 & .340 \\
\hline Bahamas & 7 & .015 & India & 504 & 1.078 & Poland & 201 & .430 \\
\hline Bahrain & 3 & .006 & Indonesia & 167 & 0.357 & Portugal & 73 & .156 \\
\hline Belgium & 159 & .340 & IrelandRep & 197 & 0.421 & Puerto Rico & 10 & .021 \\
\hline Belize & 6 & .013 & Isle of Man & 17 & 0.036 & Qatar & 12 & .026 \\
\hline Bermuda & 72 & .154 & Israel & 205 & 0.438 & Romania & 4 & .009 \\
\hline Brazil & 373 & .798 & Italy & 323 & 0.691 & Russian Fed & 159 & .340 \\
\hline British Virgin & 6 & .013 & Japan & 3314 & 7.088 & Saudi Arabia & 15 & .032 \\
\hline Bulgaria & 9 & .019 & Jersey & 11 & 0.024 & Singapore & 579 & 1.238 \\
\hline Cambodia & 1 & .002 & Jordan & 6 & 0.013 & Slovak Rep & 2 & .004 \\
\hline Canada & 3813 & 8.155 & Kenya & 1 & 0.002 & Slovenia & 15 & .032 \\
\hline Cayman Islands & 9 & .019 & Kuwait & 38 & 0.081 & South Africa & 417 & .892 \\
\hline Chile & 72 & .154 & Latvia & 1 & 0.002 & South Korea & 1282 & 2.742 \\
\hline China & 2483 & 5.310 & Lebanon & 4 & 0.009 & Spain & 395 & .845 \\
\hline Colombia & 35 & .075 & Liechtenstein & 1 & 0.002 & Sri Lanka & 5 & .011 \\
\hline Croatia & 8 & .017 & Luxembourg & 29 & 0.062 & Sweden & 555 & 1.187 \\
\hline Cyprus & 31 & .066 & Malaysia & 1279 & 2.735 & Switzerland & 248 & .530 \\
\hline Czech Republic & 13 & .028 & Malta & 4 & 0.009 & Taiwan & 279 & .597 \\
\hline Denmark & 141 & .302 & Mexico & 94 & 0.201 & Tanzania & 1 & .002 \\
\hline Egypt & 28 & .060 & Morocco & 5 & 0.011 & Thailand & 249 & .533 \\
\hline Estonia & 9 & .019 & Namibia & 1 & 0.002 & Togo & 1 & .002 \\
\hline Faroe Islands & 1 & .002 & Neth Antilles & 5 & 0.011 & Turkey & 77 & .165 \\
\hline Finland & 279 & .597 & Netherlands & 311 & 0.665 & Ukraine & 6 & .013 \\
\hline France & 713 & 1.525 & New Zealand & 80 & 0.171 & United Kingdom & 5157 & 11.029 \\
\hline Germany & 483 & 1.033 & Nigeria & 2 & 0.004 & United States & 17434 & 37.286 \\
\hline Ghana & 4 & .009 & Norway & 321 & 0.687 & Uruguay & 1 & .002 \\
\hline Gibraltar & 4 & .009 & Oman & 5 & 0.011 & Utd Arab Em & 19 & .041 \\
\hline Greece & 169 & .361 & Pakistan & 4 & 0.009 & Venezuela & 7 & .015 \\
\hline Guernsey & 33 & .071 & Panama & 2 & 0.004 & Vietnam & 20 & .043 \\
\hline \multicolumn{7}{|c|}{ Total } & 46758 & 100.0 \\
\hline
\end{tabular}


Appendix 3: M\&A Deals According to Years of Study

\begin{tabular}{lccccc}
\hline Year & No & $\%$ & Year & No & $\%$ \\
\hline 1977 & 1 & 0.002 & 1995 & 1331 & 2.847 \\
1978 & 18 & 0.038 & 1996 & 1651 & 3.531 \\
1979 & 10 & 0.021 & 1997 & 1937 & 4.143 \\
1980 & 46 & 0.098 & 1998 & 2021 & 4.322 \\
1981 & 242 & 0.518 & 1999 & 2214 & 4.735 \\
1982 & 273 & 0.584 & 2000 & 2633 & 5.631 \\
1983 & 356 & 0.761 & 2001 & 1942 & 4.153 \\
1984 & 401 & 0.858 & 2002 & 1571 & 3.360 \\
1985 & 203 & 0.434 & 2003 & 1743 & 3.728 \\
1986 & 304 & 0.650 & 2004 & 2274 & 4.863 \\
1987 & 358 & 0.766 & 2005 & 2589 & 5.537 \\
1988 & 425 & 0.909 & 2006 & 3071 & 6.568 \\
1989 & 520 & 1.112 & 2007 & 3512 & 7.511 \\
1990 & 371 & 0.793 & 2008 & 2898 & 6.198 \\
1991 & 471 & 1.007 & 2009 & 2376 & 5.081 \\
1992 & 634 & 1.356 & 2010 & 2628 & 5.620 \\
1993 & 866 & 1.852 & 2011 & 2708 & 5.792 \\
1994 & 1134 & 2.425 & 2012 & 1026 & 2.194 \\
\hline \multicolumn{7}{c}{ Total } & & 46758 & 100 \\
\hline
\end{tabular}




\section{Appendix 4: No of M\&As based on Acquirer Industry}

\begin{tabular}{|c|c|c|c|c|c|}
\hline \multicolumn{6}{|c|}{ Acquirer Mid Industry } \\
\hline Mid Industry & No. & $\%$ & Mid Industry & No. & $\%$ \\
\hline Advertising \& Marketing & 535 & 1.14 & IT Consulting \& Services & 1469 & 3.14 \\
\hline Aerospace \& Defense & 349 & 0.75 & Legal Services & 5 & 0.01 \\
\hline Agriculture \& Livestock & 262 & 0.56 & Machinery & 1118 & 2.39 \\
\hline Alternative Energy Sources & 82 & 0.18 & Metals \& Mining & 3530 & 7.55 \\
\hline Alternative Financial Investments & 371 & 0.79 & Motion Pictures / Audio Visual & 389 & 0.83 \\
\hline Apparel Retailing & 115 & 0.25 & National Agency & 1 & 0.00 \\
\hline Asset Management & 578 & 1.24 & Non Residential & 106 & 0.23 \\
\hline Automobiles \& Components & 778 & 1.66 & Oil \& Gas & 2362 & 5.05 \\
\hline Automotive Retailing & 150 & 0.32 & Other Consumer Products & 910 & 1.95 \\
\hline Banks & 3895 & 8.33 & Other Energy \& Power & 223 & 0.48 \\
\hline Biotechnology & 382 & 0.82 & Other Financials & 1574 & 3.37 \\
\hline Broadcasting & 286 & 0.61 & Other Healthcare & 6 & 0.01 \\
\hline Brokerage & 449 & 0.96 & Other High Technology & 69 & 0.15 \\
\hline Building/Construction \& Engineering & 1371 & 2.93 & Other Industrials & 945 & 2.02 \\
\hline Cable & 167 & 0.36 & Other Materials & 130 & 0.28 \\
\hline Casinos \& Gaming & 145 & 0.31 & Other Media \& Entertainment & 5 & 0.01 \\
\hline Chemicals & 854 & 1.83 & Other Real Estate & 794 & 1.70 \\
\hline Computers \& Electronics Retailing & 122 & 0.26 & Other Retailing & 341 & 0.73 \\
\hline Computers \& Peripherals & 931 & 1.99 & Other Telecom & 91 & 0.19 \\
\hline Construction Materials & 597 & 1.28 & Paper \& Forest Products & 443 & 0.95 \\
\hline Containers \& Packaging & 288 & 0.62 & Petrochemicals & 152 & 0.33 \\
\hline Credit Institutions & 152 & 0.33 & Pharmaceuticals & 1012 & 2.16 \\
\hline Discount and Department Store Retailing & 256 & 0.55 & Pipelines & 67 & 0.14 \\
\hline Diversified Financials & 16 & 0.03 & Power & 623 & 1.33 \\
\hline Ecommerce / B2B & 135 & 0.29 & Professional Services & 1293 & 2.77 \\
\hline Educational Services & 146 & 0.31 & Public Administration & 6 & 0.01 \\
\hline Electronics & 1004 & 2.15 & Publishing & 583 & 1.25 \\
\hline Employment Services & 249 & 0.53 & Real Estate Management & 229 & 0.49 \\
\hline Food \& Beverage Retailing & 576 & 1.23 & Recreation \& Leisure & 154 & 0.33 \\
\hline Food and Beverage & 1360 & 2.91 & REITs & 699 & 1.49 \\
\hline Government Sponsored Enterprises & 2 & 0.00 & Residential & 27 & 0.06 \\
\hline Healthcare Equipment \& Supplies & 1016 & 2.17 & Semiconductors & 765 & 1.64 \\
\hline Healthcare Providers \& Services (HMOs) & 610 & 1.30 & Software & 1810 & 3.87 \\
\hline Home Furnishings & 172 & 0.37 & Space and Satellites & 26 & 0.06 \\
\hline Home Improvement Retailing & 40 & 0.09 & Supranational & 2 & 0.00 \\
\hline Hospitals & 142 & 0.30 & Telecommunications Equipment & 602 & 1.29 \\
\hline Hotels and Lodging & 230 & 0.49 & Telecommunications Services & 750 & 1.60 \\
\hline Household \& Personal Products & 235 & 0.50 & Textiles \& Apparel & 666 & 1.42 \\
\hline Industrial Conglomerates & 47 & 0.10 & Tobacco & 48 & 0.10 \\
\hline Insurance & 789 & 1.69 & Transportation \& Infrastructure & 897 & 1.92 \\
\hline Internet and Catalog Retailing & 138 & 0.30 & Travel Services & 105 & 0.22 \\
\hline Internet Infrastructure & 1 & 0.00 & Water and Waste Management & 349 & 0.75 \\
\hline Internet Software \& Services & 1008 & 2.16 & Wireless & 351 & 0.75 \\
\hline & & & Total & 46758 & 100.00 \\
\hline
\end{tabular}




\section{Appendix 5: Number of M\&As based on Target Industry}

\begin{tabular}{|c|c|c|c|c|c|}
\hline \multicolumn{6}{|c|}{ Target Mid Industry } \\
\hline Mid Industry & No. & $\%$ & Mid Industry & No. & $\%$ \\
\hline Advertising \& Marketing & 546 & 1.17 & IT Consulting \& Services & 1474 & 3.15 \\
\hline Aerospace \& Defense & 227 & 0.49 & Legal Services & 9 & 0.02 \\
\hline Agriculture \& Livestock & 302 & 0.65 & Machinery & 1091 & 2.33 \\
\hline Alternative Energy Sources & 85 & 0.18 & Metals \& Mining & 3504 & 7.49 \\
\hline Alternative Financial Investments & 90 & 0.19 & $\begin{array}{l}\text { Motion Pictures / Audio } \\
\text { Visual }\end{array}$ & 373 & 0.80 \\
\hline Apparel Retailing & 139 & 0.30 & National Agency & 1 & 0.00 \\
\hline Asset Management & 552 & 1.18 & Non Residential & 352 & 0.75 \\
\hline Automobiles \& Components & 691 & 1.48 & Oil \& Gas & 2372 & 5.07 \\
\hline Automotive Retailing & 158 & 0.34 & Other Consumer Products & 986 & 2.11 \\
\hline Banks & 3498 & 7.48 & Other Energy \& Power & 196 & 0.42 \\
\hline Biotechnology & 366 & 0.78 & Other Financials & 1989 & 4.25 \\
\hline Broadcasting & 277 & 0.59 & Other Healthcare & 1 & 0.00 \\
\hline Brokerage & 514 & 1.10 & Other High Technology & 26 & 0.06 \\
\hline Building/Construction \& Engineering & 1381 & 2.95 & Other Industrials & 886 & 1.89 \\
\hline Cable & 152 & 0.33 & Other Materials & 217 & 0.46 \\
\hline Casinos \& Gaming & 91 & 0.19 & Other Media \& Entertainment & 9 & 0.02 \\
\hline Chemicals & 781 & 1.67 & Other Real Estate & 936 & 2.00 \\
\hline City Agency & 1 & 0.00 & Other Retailing & 433 & 0.93 \\
\hline Computers \& Electronics Retailing & 141 & 0.30 & Other Telecom & 73 & 0.16 \\
\hline Computers \& Peripherals & 812 & 1.74 & Paper \& Forest Products & 394 & 0.84 \\
\hline Construction Materials & 521 & 1.11 & Petrochemicals & 138 & 0.30 \\
\hline Containers \& Packaging & 299 & 0.64 & Pharmaceuticals & 856 & 1.83 \\
\hline Credit Institutions & 257 & 0.55 & Pipelines & 100 & 0.21 \\
\hline $\begin{array}{l}\text { Discount and Department Store } \\
\text { Retailing }\end{array}$ & 134 & 0.29 & Power & 567 & 1.21 \\
\hline Diversified Financials & 42 & 0.09 & Professional Services & 1893 & 4.05 \\
\hline Ecommerce / B2B & 146 & 0.31 & Public Administration & 4 & 0.01 \\
\hline Educational Services & 201 & 0.43 & Publishing & 501 & 1.07 \\
\hline Electronics & 845 & 1.81 & $\begin{array}{l}\text { Real Estate Management \& } \\
\text { Development }\end{array}$ & 243 & 0.52 \\
\hline Employment Services & 235 & 0.50 & Recreation \& Leisure & 263 & 0.56 \\
\hline Food \& Beverage Retailing & 604 & 1.29 & REITs & 398 & 0.85 \\
\hline Food and Beverage & 1287 & 2.75 & Residential & 53 & 0.11 \\
\hline Government Sponsored Enterprises & 8 & 0.02 & Semiconductors & 702 & 1.50 \\
\hline Healthcare Equipment \& Supplies & 1134 & 2.43 & Software & 2207 & 4.72 \\
\hline $\begin{array}{l}\text { Healthcare Providers \& Services } \\
\text { (HMOs) }\end{array}$ & 575 & 1.23 & Space and Satellites & 19 & 0.04 \\
\hline Home Furnishings & 161 & 0.34 & $\begin{array}{l}\text { Telecommunications } \\
\text { Equipment }\end{array}$ & 533 & 1.14 \\
\hline Home Improvement Retailing & 76 & 0.16 & Telecommunications Services & 660 & 1.41 \\
\hline Hospitals & 164 & 0.35 & Textiles \& Apparel & 577 & 1.23 \\
\hline Hotels and Lodging & 298 & 0.64 & Tobacco & 31 & 0.07 \\
\hline Household \& Personal Products & 164 & 0.35 & $\begin{array}{l}\text { Transportation \& } \\
\text { Infrastructure }\end{array}$ & 971 & 2.08 \\
\hline Insurance & 831 & 1.78 & Travel Services & 133 & 0.28 \\
\hline Internet and Catalog Retailing & 112 & 0.24 & Water and Waste Management & 346 & 0.74 \\
\hline Internet Infrastructure & 1 & 0.00 & Wireless & 324 & 0.69 \\
\hline Internet Software \& Services & 1018 & 2.18 & Total & 46758 & 100.00 \\
\hline
\end{tabular}




\section{Appendix 6: Number of M\&As for Acquirer and Target Industries}

\begin{tabular}{|c|c|c|c|c|c|c|c|c|c|c|c|c|c|c|c|}
\hline \multicolumn{16}{|c|}{ Macro Industry } \\
\hline $\begin{array}{ll}\text { Acquirer } & \text { Target } \\
\end{array}$ & (1) & $(2)$ & (3) & (4) & $(5)$ & (6) & (7) & (8) & (9) & $(10)$ & $(11)$ & (12) & (13) & Total & $\%$ \\
\hline $\begin{array}{l}\text { (1) Consumer Products \& } \\
\text { Services }\end{array}$ & 1265 & 107 & 69 & 170 & 2 & 163 & 379 & 263 & 130 & 133 & 62 & 106 & 31 & 2880 & 6.16 \\
\hline (2) Consumer Staples & 142 & 1600 & 43 & 124 & 0 & 75 & 53 & 137 & 163 & 41 & 58 & 125 & 10 & 2571 & 5.50 \\
\hline (3) Energy and Power & 95 & 25 & 2822 & 180 & 0 & 15 & 96 & 301 & 196 & 29 & 27 & 36 & 36 & 3858 & 8.25 \\
\hline (4) Financials & 264 & 103 & 139 & 6047 & 3 & 87 & 268 & 229 & 227 & 136 & 192 & 78 & 53 & 7826 & 16.74 \\
\hline $\begin{array}{l}\text { (5) Government \& } \\
\text { Agencies }\end{array}$ & 1 & 0 & 0 & 1 & 0 & 2 & 0 & 1 & 3 & 0 & 1 & 0 & 0 & 9 & 0.02 \\
\hline (6) Healthcare & 300 & 38 & 16 & 86 & 0 & 2339 & 104 & 97 & 67 & 16 & 29 & 62 & 14 & 3168 & 6.78 \\
\hline (7) High Technology & 516 & 38 & 99 & 263 & 0 & 127 & 4769 & 387 & 149 & 290 & 48 & 111 & 395 & 7192 & 15.38 \\
\hline (8) Industrials & 360 & 106 & 268 & 249 & 1 & 107 & 463 & 3050 & 446 & 76 & 199 & 88 & 92 & 5505 & 11.77 \\
\hline (9) Materials & 147 & 164 & 268 & 199 & 0 & 80 & 152 & 461 & 4170 & 54 & 90 & 31 & 26 & 5842 & 12.49 \\
\hline $\begin{array}{l}\text { (10) Media \& } \\
\text { Entertainment }\end{array}$ & 254 & 26 & 10 & 88 & 0 & 15 & 314 & 58 & 41 & 1488 & 52 & 80 & 68 & 2494 & 5.33 \\
\hline (11) Real Estate & 60 & 21 & 24 & 213 & 0 & 40 & 39 & 111 & 54 & 91 & 1153 & 40 & 9 & 1855 & 3.97 \\
\hline (12) Retail & 136 & 124 & 21 & 94 & 0 & 31 & 89 & 66 & 36 & 58 & 61 & 1012 & 10 & 1738 & 3.72 \\
\hline (13) Telecommunications & 78 & 9 & 25 & 67 & 0 & 15 & 505 & 86 & 34 & 98 & 10 & 28 & 865 & 1820 & 3.89 \\
\hline Total & 3618 & 2361 & 3804 & 7781 & 6 & 3096 & 7231 & 5247 & 5716 & 2510 & 1982 & 1797 & 1609 & 46758 & 100 \\
\hline$\%$ & 7.74 & 5.05 & 8.14 & 16.64 & 0.01 & 6.62 & 15.46 & 11.22 & 12.22 & 5.37 & 4.24 & 3.84 & 3.44 & 100 & \\
\hline
\end{tabular}

